\title{
Communication \\ Changes in Soil Chemical Properties Due to Long-Term Compost Fertilization Regulate Methane Turnover Related Gene Abundances in Rice Paddy
}

\author{
Chungwoo Kim ${ }^{1,2,+}{ }^{\dagger}$, Denver I. Walitang ${ }^{1,3,+}{ }^{\oplus}$, Aritra Roy Choudhury ${ }^{1,4} \oplus^{(}$, Yi Lee ${ }^{5}\left(\mathbb{C}\right.$, Sanghun Lee ${ }^{6}$, \\ Hyenchung Chun ${ }^{6}$, Tae-Young Heo ${ }^{7}$, Kido Park ${ }^{6}$ and Tongmin Sa ${ }^{1,8, *(1)}$
}

Citation: Kim, C.; Walitang, D.I.; Roy Choudhury, A.; Lee, Y.; Lee, S.; Chun,

H.; Heo, T.-Y.; Park, K.; Sa, T.

Changes in Soil Chemical Properties Due to Long-Term Compost Fertilization Regulate Methane Turnover Related Gene Abundances in Rice Paddy. Appl. Sci. 2022, 12, 2652. https://doi.org/10.3390/ app12052652

Academic Editor: Rafael López Núñez

Received: 27 November 2021

Accepted: 2 March 2022

Published: 4 March 2022

Publisher's Note: MDPI stays neutral with regard to jurisdictional claims in published maps and institutional affiliations.

Copyright: (c) 2022 by the authors. Licensee MDPI, Basel, Switzerland. This article is an open access article distributed under the terms and conditions of the Creative Commons Attribution (CC BY) license (https:// creativecommons.org/licenses/by/ $4.0 /)$.
1 Department of Environmental and Biological Chemistry, Chungbuk National University, Cheongju 28644, Korea; chungwoo77@korea.kr (C.K.); denver82@chungbuk.ac.kr (D.I.W.); aritraroy@kribb.re.kr (A.R.C.)

2 Chungcheongbuk-do Agricultural Research and Extension Services, Cheongju 28130, Korea

3 College of Agriculture, Fisheries and Forestry, Romblon State University, Romblon 5505, Philippines

4 Bio-Evaluation Center, Korea Research Institute of Bioscience and Biotechnology, Cheongju 28116, Korea

5 Department of Industrial Plant Science and Technology, Chungbuk National University, Cheongju 28644, Korea; leeyi22@hanmail.net

6 Rural Development Administration, Miryang 50424, Korea; sangusa@korea.kr (S.L.); hyen2010@korea.kr (H.C.); pkd@korea.kr (K.P.)

7 Department of Information and Statistics, Chungbuk National University, Cheongju 28644, Korea; theo@chungbuk.ac.kr

8 The Korean Academy of Science and Technology, Seongnam 13630, Korea

* Correspondence: tomsa@chungbuk.ac.kr

+ These authors have contributed equally to this work.

\begin{abstract}
Maintaining rice yield, soil function, and fertility are essential components of long-term compost fertilization. However, paddy fields are major sources of anthropogenic methane emissions. The aim of the study is to evaluate the changes in soil chemical properties and their concurrent impact on the abundance of methanogenesis $(m c r A)$ and methane oxidation ( $p m o A)$ related genes among compost (Com), NPK+Compost (NPKCom), and unfertilized (NF) fallow paddy fields under longterm compost fertilization. Results showed that compost and NPK+Compost fertilization altered the soil chemical properties of paddy fields with a significant increase in the functional gene abundance potentially associated with Methanobacteriaceae for $m c r A\left(1.23 \times 10^{6}\right.$ to $3.84 \times 10^{6}$ copy number $\mathrm{g}^{-1}$ dry soil) and methane oxidizing bacteria such as Methylomonas and Methylobacter for pmoA $\left(1.65 \times 10^{6}\right.$ to $4.3 \times 10^{6}$ copy number $\mathrm{g}^{-1}$ dry soil $)$. Ordination plots visualized these changes, where treatments clustered distinctly indicating that Com and NPKCom treatments were characterized by paddy soils with elevated $\mathrm{OM}, \mathrm{TN}, \mathrm{K}$ and $\mathrm{P}$ content and higher abundances of methanogenesis and methane oxidation related genes. The study showed that long-term compost fertilization resulted in paddy fields with high nutrient content and high gene abundance, attributed to methanogens and methane oxidizing bacteria that responded well with compost fertilization. These results indicated the potential of these fallow paddy fields for methane emission and methane oxidation and that they are 'primed', potentially influencing subsequent paddy field responses to long-term compost application.
\end{abstract}

Keywords: long-term compost fertilization; soil chemical properties; functional gene abundance; paddy soils; rice fallow period; methane emission; methanogenesis; methane oxidation; $m c r A ; p m o A$

\section{Introduction}

Climate change and global warming are two of the most important environmental issues that mankind must overcome. Thus, soil quality evaluation, previously based mainly on productivity and economic value, needs to incorporate soil physicochemical 
and microbial components as critical indicators of sustainable agriculture to mitigate environmental issues [1-3]. In conjunction, methane as a greenhouse gas is a major factor in global warming [4]. The global methane emissions in 2017 reached a record with $600 \mathrm{Tg} \mathrm{CH}_{4} \mathrm{yr}^{-1}$ of which $61 \%$ was anthropogenic primarily from agriculture-related sources [5]. Rice paddies are major sources of methane, generating approximately $11 \%$ of global anthropogenic methane emissions [6,7]. Methane emission dynamically changes in different soil types under aerobic and anaerobic states dictated by the balance of methane production through methanogenesis and methane oxidation [8].

Long-term compost application, alone or in combination with inorganic fertilizers such as NPK, has been adapted to combat interrelated environmental problems such as soil degradation and unsustainable land use, leading to beneficial impacts such as improved soil carbon sequestration, biodiversity, biogeochemical cycles, fertility, and crop yield [9]. Although compost fertilization plays a positive role in climate change mitigation through soil carbon sequestration, its role in increased methane emission is well documented, particularly in paddy fields under submerged conditions [10,11]. In addition, compost fertilization could affect the physicochemical and biological components of soil paddy fields, which ultimately reflects on the soil biogeochemical processes affecting methane emission [12].

We have greatly expanded our understanding of methanogenesis and methane oxidation and their links to processes and factors such as global warming and greenhouse gas emissions, soil functions, and edaphic components $[4,8]$. We have also improved on precision agriculture, maximizing yield with optimal input. Extensive studies on these processes allow us to analyze and create an overview for larger or long-term scale scenarios and to incorporate potential environmental impact [6,7], helping develop models to help understand and mitigate environmental issues [1]. However, these models are prone to uncertainties due to different factors such as data measurement or availability of data and the interactions to multiple processes [1].

For instance, the conditions and links between soil chemistry and the abundance of methane-related functional genes occurring during the non-growing period of rice (fallow period) established due to long-term compost fertilization have been understudied as most investigations mainly focused on the rice planting season. Fallow paddy fields show potential fluxes for greenhouse gas emissions, which could extend from one to three months [12] and could be exacerbated when submerged, leading to significant methane emissions [13]. Paddy fields with a history of fertilization may respond more actively and strongly to methanogenesis and methane oxidation [14,15]. Potential responses to different fertilizations are mainly linked with the microbial communities present in these paddy fields [16]. Methanogenic archaea [4,17] and methane oxidizing bacteria from type I and type II methanotrophs $[4,18]$ complicate the processes as they respond differently to fertilization and other contributing factors and may lead to varying results [14]. Therefore, monitoring soil biological and chemical conditions in fallow paddy fields should be strengthened as these conditions may drive actual methanogenesis and methane oxidation occurring during the fallow period. Soil conditions established in fallow paddy fields also greatly influence the paddy field responses to continued long-term fertilization in relation to methane emission.

Thus, the study was conducted to gain more insight into the potential contributions and conditions of fallow paddy field agricultural systems under long-term fertilization related to methane emission. Particularly, this study was conducted to evaluate the changes in soil chemical properties that may subsequently affect the abundance of methanogenesis and methane oxidation functional genes present, even during fallow periods in paddy fields under long-term compost fertilization. We hypothesized that long-term compost fertilization results in alterations of the soil chemistry, concurrently driving the changes in functional gene abundance that could become baseline soil conditions in long-term compostamended paddy fields. Specifically, we posited that long-term compost fertilization will result in the accumulation of organic matter relative to unfertilized paddy fields, which 
could also be true for other soil chemical properties. In addition, the combination of NPK and compost application may also result in significant changes in the chemical contents of paddy fields especially N, P, and K, which could also differently affect the abundance of methane-related functional genes. These changes under long-term compost fertilization potentially become established even after the growing season, especially during fallow periods.

\section{Materials and Methods}

\subsection{Field Experimental Design and Soil Sampling}

The study site was located at the Rural Development Administration (RDA), Miryang, South Korea (latitude 36 $36^{\prime} \mathrm{N}$; longitude $128^{\circ} 45^{\prime} \mathrm{E}$ ). Long-term fertilization started in 1967 and rice was cultivated as a monocrop [19]. A completely randomized arrangement for the experimental area was done with $10 \mathrm{~m} \times 10 \mathrm{~m}$ plots replicated three times for each treatment. Different compost fertilization treatments, with and without inorganic NPK additions, were selected for the study. The treatments included: (a) unfertilized control (NF), (b) NPK fertilizers plus compost (NPKCom), and (c) compost (Com). Urea (N), fused superphosphate $(\mathrm{P})$, and potassium chloride (K) (NPK), were added at ate of 120, 80 and $80 \mathrm{~kg} \mathrm{ha}^{-1}$ from 1967 to 1972 . Before the transplantation of rice seedlings, NPK was added as the basal fertilizer, which supplied 50,100 and 70\% of N, P and K, respectively. The rice straw and the cattle manure compost were decomposed for a minimum of 6 months, containing approximately 431, 19.8, 5.2 and $29.1 \mathrm{~g} \mathrm{~kg}^{-1}$ of total C, N, P and K, respectively. An equivalent of 10 tons ha ${ }^{-1}$ was amended for compost treatments. Soil sampling was done in April 2021 during the rice fallow period before submergence with water and the transplantation of rice seedlings. Five subsample soils were taken at a depth of nearly $20 \mathrm{~cm}$ from each of the three replicates belonging to individual treatments. A single composite sample was created for each treatment by pooling the subsamples together. The composite samples were sieved $(<2 \mathrm{~mm})$ after the removal of visible rock and root debris. The soils were immediately stored in a sterile polypropylene bag and transported to the laboratory in ice. Soils used for DNA extraction were stored at $-80^{\circ} \mathrm{C}$, while those for routine soil chemical property analyses were stored at $4{ }^{\circ} \mathrm{C}$.

\subsection{Determination of Soil Chemical Properties}

A 1:5 soil-water suspension was prepared for soil $\mathrm{pH}$ measurement using an automatic glass pH electrode (Orion Star A215, Thermo Scientific, Waltham, MA, USA). Saturated paste extracts were prepared for the determination of electrical conductivity (EC) (1:5) of soils using an EC meter (Orion Star A215, Thermo Scientific). The Tyurin titrimetric method [20] was employed for the measurement of organic matter (OM). A standardized Kjeldahl method [21] was employed for the measurement of total N. The Lancaster method, as reported by Samaddar et al., [22], was used to measure available P. Dissolved organic carbon was measured according to Jones and Willet [23] with minor modifications, where additional filtration with Whatman No. 42 was carried out on the supernatant.

\subsection{DNA Extraction, PCR Amplification, Cloning, and Sequencing of Functional Genes}

DNA was extracted using a PowerSoil ${ }^{\circledR}$ DNA isolation kit (MO BIO Laboratories Inc., Carlsbad, CA, USA) according to the manufacturer's instructions using $\sim 0.30 \mathrm{~g}$ of fresh soil sample. The extracted DNA was stored at $-20{ }^{\circ} \mathrm{C}$ until used in downstream analyses. The quantity and the quality of the extracted DNA were determined by Nano Drop 2000 (Thermo Scientific) and gel electrophoresis. PCR amplification of methane related genes was carried out with the same PCR conditions used in $\mathrm{qPCR}$, except that a final elongation step was added at $75^{\circ} \mathrm{C}$ for 5 min and a hold temperature at $4{ }^{\circ} \mathrm{C}$ (Table S1). PCR-amplified products using genomic DNA extracted from compost-treated paddy soils were then used for cloning. The PCR products were purified using Biomedic ${ }^{\circledR}$ Gel \& PCR Purification Kit (Biomedic Co., Ltd., Bucheon, Korea). The purified PCR product was cloned into pTOP TA V2 vector using TOPclonerTM TA Kit (Enzynomics, Daejeon, Korea). The vector-insert 
ligate was used to transform Escherichia coli DH5 $\alpha$ competent cells (Biomedic Co., Ltd., Bucheon, Korea) and then E. coli transformants were cultured on Luria-Bertani (LB) solid broth containing ampicillin/IPTG/X-gal for $12 \mathrm{~h}$ at $37^{\circ} \mathrm{C}$. White colonies were inoculated in LB liquid broth containing ampicillin $(50 \mathrm{ug} / \mathrm{uL}$ ) and then cultured in a shaking incubator (180 rpm) for $12 \mathrm{~h}$ at $37^{\circ} \mathrm{C}$. In order to identify recombinant clones, white colonies were subjected to colony PCR using vector primer sets, M13 forward, and M13 reverse primers. The PCR cycling condition was as follows: $5 \mathrm{~min}$ for initial denaturation at $94{ }^{\circ} \mathrm{C}, 25$ cycles of $30 \mathrm{~s}$ at $94^{\circ} \mathrm{C}, 30 \mathrm{~s}$ at $55^{\circ} \mathrm{C}, 1 \mathrm{~min}$ at $72{ }^{\circ} \mathrm{C}$, concluding with 1 cycle of $10 \mathrm{~min}$ at $72{ }^{\circ} \mathrm{C}$. The PCR product was separated on $1.2 \%(w / v)$ agarose gel to check PCR amplification. Plasmid DNAs were isolated from the recombinant clones using Biomedic ${ }^{\circledR}$ Plasmid DNA Miniprep Kit (Biomedic Co., Ltd., Bucheon, Korea) following the manufacturer's protocol. Nucleotide sequences of the recombinant clones were determined using the two vector primers and dGTP BigDye ${ }^{\circledR}$ Terminator v3.0 Ready Reaction Cycle Sequencing Kit (Applied Biosystems, Foster City, CA, USA) following the manufacturer's guide. The obtained functional gene sequences were aligned and the affiliations were deduced using BLAST analysis using the NCBI (https:/ /blast.ncbi.nlm.nih.gov/) [24]. Phylogenetic analyses were performed using MEGA version 6 [25] after multiple alignments of the data by CLUSTAL W [26]. DNA substitutions were done according to the Jukes and Cantor model [27] and clustering was performed using the neighbor-joining method [28]. The statistical confidence of the nodes was estimated by bootstrapping using 1000 replications [29]. Sequences of the $m c r A$ and pmo $A$ genes were deposited in GenBank and the accession numbers of the entries were OL739247 to OL739249 for $m c r A$ and OL691942 to OL691960 for the pmoA gene sequences.

\subsection{Quantitative PCR}

Quantitative Real-Time PCR (qPCR) was applied for the quantification of methanogenic archaeal marker gene $m c r A$ and methanotrophic bacterial marker gene $p m o A$. The qPCR assays were performed using CFX96 ${ }^{\mathrm{TM}}$ Real-Time System PCR, (Bio-Rad, Hercules, CA, USA). A stock solution of target sequence containing plasmid was used to create a serially diluted standard curve for each functional gene, ranging from $10^{4}$ to $10^{8}$ copies. The optimized qPCR reactions were performed in $10 \mu \mathrm{L}$ volume containing $5 \mu \mathrm{L}$ SYBR Green Master Mix (Thermo Fisher Scientific Inc., Waltham, MA, USA), $0.8 \mu \mathrm{L}$ of forward and reverse primers, $1 \mu \mathrm{L}$ of template DNA, and sterile distilled water. The optimized reaction conditions for each target gene are described in Table S1. All qPCR measurements were performed in triplicates and negative controls were included in each qPCR run.

\subsection{Statistical Analysis}

The soil properties and the gene abundance were subjected to statistical analysis to check the significant differences of variables among the treatments. Analysis of Variance (ANOVA) was performed to compare the means of soil chemical properties following Tukey's test at $p<0.05$ [30]. K-means clustering and the heatmap figure of the different treatments based on soil chemical properties were constructed using the online tool ClustVis [31]. The Pearson correlation between the abundance of methane cycling related genes and soil chemical properties was conducted using SAS [30]. The principal component analysis (PCA) and the plotting were produced with the R statistical software version 4.1.1 (R Core Team, 2021) with the pca3D, ggfortify, and mixOmics packages [32-34] and in SAS [30].

\section{Results}

Long-term compost fertilization either as compost alone (Com) or a combination of compost and inorganic fertilizers (NPKCom) changed the soil chemical properties of paddy fields (Tables 1 and 2). The ANOVA results showed that there are significant mean differences in the soil chemical properties across treatments, especially for $\mathrm{pH}, \mathrm{OM}, \mathrm{TN}, \mathrm{P}$, $\mathrm{K}, \mathrm{Ca}$ and DOC. Some of the changes in chemical properties include a significant increase in organic matter $(\mathrm{OM})$ content, total nitrogen $(\mathrm{TN})$, phosphorus $(\mathrm{P})$, and potassium $(\mathrm{K})$ 
in both Com and NPKCom treatments. The nutrients $\mathrm{Ca}^{2+}$ and $\mathrm{Mg}^{2+}$ were observed to be significantly higher in the NPKCom treatment, while dissolved organic carbon (DOC) is significantly higher in the Com treatment. The $\mathrm{pH}$ in NPKCom has also become significantly less acidic than in the Com treatment, but not significantly different than the unfertilized control.

Using quantitative Real-Time PCR (qPCR), the absolute abundance of $m c r A$ and $p m o A$ genes was quantified in the paddy soils fertilized with compost and $\mathrm{NPK}+\mathrm{Compost}$. There is more than a three-fold statistically significant increase in the abundance of $m c r A$ genes in the Com and NPKCom treatments (Table 2), which ranged from $1.23 \times 10^{6}$ to $3.47 \times 10^{6}$ copy number $\mathrm{g}^{-1}$ dry soil. The $p m o A$ gene abundance also increased significantly by 2.61 -fold $\left(4.31 \times 10^{6}\right.$ copy number $\mathrm{g}^{-1}$ dry soil $)$ and 2.47 -fold $\left(4.08 \times 10^{6}\right.$ copy number $\mathrm{g}^{-1}$ dry soil) in compost and NPK+Compost-fertilized paddy fields, respectively, compared to the unfertilized control $\left(1.65 \times 10^{6}\right.$ copy number $\mathrm{g}^{-1}$ dry soil).

Table 1. ANOVA summary table for the soil chemical parameters in paddy fields under long-term compost fertilization.

\begin{tabular}{ccccccc}
\hline Parameter & DF & $\begin{array}{c}\text { Sum of } \\
\text { Squares }\end{array}$ & $\begin{array}{c}\text { Mean } \\
\text { Square }\end{array}$ & F Value & Pr $>$ F & $\begin{array}{c}\text { Number of } \\
\text { Observations }\end{array}$ \\
\hline $\mathrm{pH}$ & 4 & 0.529 & 0.132 & 7.91 & 0.0350 & 9 \\
$\mathrm{EC}$ & 4 & 0.196 & 0.049 & 0.15 & 0.9513 & 9 \\
$\mathrm{OM}$ & 4 & 1.149 & 0.287 & 15.41 & 0.0107 & 9 \\
$\mathrm{TN}$ & 4 & 0.009 & 0.002 & 43.01 & 0.0015 & 9 \\
$\mathrm{P}_{2} \mathrm{O}_{5}$ & 4 & 20640 & 5160 & 55.52 & 0.0009 & 9 \\
$\mathrm{~K}$ & 4 & 0.298 & 0.075 & 43.16 & 0.0015 & 9 \\
$\mathrm{Ca}$ & 4 & 4.989 & 1.247 & 6.58 & 0.0476 & 9 \\
$\mathrm{Mg}$ & 4 & 0.662 & 0.167 & 3.95 & 0.1060 & 9 \\
$\mathrm{DOC}$ & 4 & 3926 & 981.5 & 6.89 & 0.0441 & 9 \\
\hline
\end{tabular}

Table 2. Soil chemical properties and abundance of methane cycling related genes of long-term compost-fertilized paddy fields.

\begin{tabular}{|c|c|c|c|c|c|c|c|c|c|c|c|}
\hline \multirow{2}{*}{ Treatment } & $\mathrm{pH}$ & EC & OM & TN & $\mathrm{P}_{2} \mathrm{O}_{5}$ & K & $\mathrm{Ca}$ & $\mathrm{Mg}$ & \multirow{2}{*}{$\frac{\text { DOC }}{\left(\mathrm{mg} \mathrm{kg}^{-1}\right)}$} & $m c r A$ & $p m o A$ \\
\hline & (1:5) & $\left(\mathrm{dS} \mathrm{m}^{-1}\right)$ & $(\%)$ & $(\%)$ & $\left(\mathrm{mg} \mathrm{kg}^{-1}\right)$ & \multicolumn{3}{|c|}{$\left(\mathrm{cmol} \mathrm{kg}^{-1}\right)$} & & \multicolumn{2}{|c|}{ Copy Number $\mathrm{g}^{-1}$ Dry Soil } \\
\hline $\mathrm{NF}$ & $5.80 \mathrm{ab}$ & $0.90 \mathrm{a}$ & $2.1 \mathrm{~b}$ & $0.15 b$ & $28 \mathrm{c}$ & $0.13 \mathrm{~b}$ & $5.7 \mathrm{~b}$ & $1.13 \mathrm{~b}$ & $53 \mathrm{~b}$ & $1.20 \times 10^{6} \mathrm{~b}$ & $1.60 \times 10^{6} \mathrm{~b}$ \\
\hline NPKCom & $5.99 \mathrm{a}$ & $1.23 \mathrm{a}$ & $2.9 \mathrm{a}$ & $0.22 \mathrm{a}$ & $141 \mathrm{a}$ & $0.53 \mathrm{a}$ & $7.3 \mathrm{a}$ & $1.71 \mathrm{a}$ & $74 \mathrm{ab}$ & $3.47 \times 10^{6} \mathrm{a}$ & $4.08 \times 10^{6} \mathrm{a}$ \\
\hline Com & $5.64 \mathrm{~b}$ & $1.09 \mathrm{a}$ & $2.7 \mathrm{a}$ & $0.21 \mathrm{a}$ & $63 \mathrm{~b}$ & $0.49 \mathrm{a}$ & $6.5 \mathrm{ab}$ & $1.22 \mathrm{~b}$ & $99 a$ & $3.42 \times 10^{6} \mathrm{a}$ & $4.31 \times 10^{6} \mathrm{a}$ \\
\hline
\end{tabular}

Mean values in the same column followed by the same letter are not significantly different at $0.05 \%$ (Tukey's, $\mathrm{n}=9$ ); NF—unfertilized control; NPKCom-chemical fertilizer (NPK)+compost; Com—compost; EC—electrical conductivity; $\mathrm{OM}$-organic matter; TN—-total nitrogen; DOC—dissolved organic carbon.

The correlation matrix (Table S2) showed that correlations exist between the gene abundance and the soil chemical properties. There is a positive and significant correlation of the $m c r A$ gene abundance with that of the $p m o A$ gene abundance. The abundance of the $m c r A$ gene is positively and significantly correlated to organic matter (OM), total nitrogen (TN), potassium (K), calcium (Ca), and DOC. These correlations for the mcrA gene abundance and the soil chemical properties were also observed at the level of the individual treatments. Overall, for the $p m o A$ gene abundance, it is positively correlated with $\mathrm{OM}, \mathrm{TN}, \mathrm{P}, \mathrm{K}$ and DOC; however, these correlations were not clearly observed at the level of each treatment.

The principal component analysis showed the overall effect of the fertilization treatment on the soil chemical properties and the gene abundance of methane-related functional genes as well as the variability that exists (Table 3). Principal components (PC) 1, 2 and 3 have eigenvalues greater than 1 (6.851, 1.859 and 1.144, respectively). PC1, PC2 and PC3 have component loadings of $0.6228,0.1690$ and 0.1040 , respectively, with a cumulative loading of $89.57 \%$. For each of the individual loading factors, TN and $\mathrm{K}$ almost equally 
contributed the greatest loading for PC1 followed by $\mathrm{OM}, \mathrm{Ca}$, and an equal contribution from $m c r A$ and $p m o A$, with these variables mainly attributing to the $62.28 \%$ variability. For the $\mathrm{PC} 2, \mathrm{pH}$ and DOC gave the highest loading, contributing mainly to the $16.90 \%$ overall variability. The soil EC is the highest loading factor in PC3, which potentially gave an additional $10.40 \%$ overall variability.

Table 3. Principle component analysis of methane cycling related functional gene abundance and soil chemical properties and their loading coefficient for the principal components.

\begin{tabular}{|c|c|c|c|c|c|c|c|c|c|c|c|}
\hline \multicolumn{3}{|c|}{ Principal Component } & \multicolumn{3}{|c|}{ Eigenvalues } & \multicolumn{3}{|c|}{ Component Loading } & \multicolumn{3}{|c|}{ Cumulative Loading } \\
\hline \multicolumn{3}{|c|}{1} & \multicolumn{3}{|c|}{6.851} & \multicolumn{3}{|c|}{0.6228} & \multicolumn{3}{|c|}{0.6228} \\
\hline \multicolumn{3}{|c|}{2} & \multicolumn{3}{|c|}{1.859} & \multicolumn{3}{|c|}{0.1690} & \multicolumn{3}{|c|}{0.7918} \\
\hline \multicolumn{3}{|c|}{3} & \multicolumn{3}{|c|}{1.144} & \multicolumn{3}{|c|}{0.1040} & \multicolumn{3}{|c|}{0.8957} \\
\hline \multicolumn{3}{|c|}{4} & \multicolumn{3}{|c|}{0.778} & \multicolumn{3}{|c|}{0.0708} & \multicolumn{3}{|c|}{0.9665} \\
\hline \multicolumn{3}{|c|}{5} & \multicolumn{3}{|c|}{0.172} & \multicolumn{3}{|c|}{0.0156} & \multicolumn{3}{|c|}{0.9821} \\
\hline \multicolumn{3}{|c|}{6} & \multicolumn{3}{|c|}{0.160} & \multicolumn{3}{|c|}{0.0146} & \multicolumn{3}{|c|}{0.9967} \\
\hline \multicolumn{3}{|c|}{7} & \multicolumn{3}{|c|}{0.027} & \multicolumn{3}{|c|}{0.0025} & \multicolumn{3}{|c|}{0.9991} \\
\hline \multirow{2}{*}{\multicolumn{3}{|c|}{8}} & & 0.009 & & & 0.0009 & & \multicolumn{3}{|c|}{1.0000} \\
\hline & & & \multicolumn{6}{|c|}{ Principal component loading for each variable } & & & \\
\hline & $m c r A$ & pmoA & $\mathrm{pH}$ & $\mathrm{EC}$ & $\mathrm{OM}$ & $\mathrm{TN}$ & $\mathrm{P}_{2} \mathrm{O}_{5}$ & K & $\mathrm{Ca}$ & $\mathrm{Mg}$ & DOC \\
\hline PC1 & 0.324 & 0.329 & 0.055 & 0.207 & 0.353 & 0.369 & 0.316 & 0.361 & 0.337 & 0.302 & 0.214 \\
\hline PC2 & -0.049 & -0.234 & 0.660 & -0.068 & -0.115 & -0.134 & 0.223 & -0.070 & 0.292 & 0.370 & -0.441 \\
\hline PC3 & 0.129 & -0.356 & -0.185 & 0.761 & -0.065 & -0.126 & -0.240 & -0.229 & 0.147 & 0.288 & 0.090 \\
\hline
\end{tabular}

The PCA ordination plot showed the grouping of the soil treatments according to their soil chemical properties and the abundance of the $m c r A$ and $p m o A$ genes (Figure 1). The distinct clustering of the Com treatments is partly influenced by DOC. The distinct clustering of the NPKCom treatment is party influenced by $\mathrm{pH}$. The combined effects of the different soil chemical parameters (OM, TN, P, K, EC, Mg and Ca) and the gene abundance $(m c r A, p m o A)$ add to the overall clustering of the different treatments under long-term compost fertilization. Similar clustering as shown through k-means clustering was also observed between the treatments due to soil chemical properties (Figure S1).

The sequencing of genes derived from PCR-amplified genomic DNA from paddy fields with compost fertilization showed distantly and closely related reference sequences attributed to methanogenesis and methane oxidation. For the $m c r A$ gene, all the sequences are distantly related to Methanobacteriaceae, which were also from environmental samples from the methanogenic archaeal community on the rice roots (Figure 2). The pmoA gene sequences showed more diverse reference strains associated with methane oxidation (Figure 3). The gene sequences have high similarity with reference strains containing the particulate methane monooxygenase gene. The most abundant gene sequences are attributed to Methylomonas sp. (8/20), followed by Methylobacter sp. (5/20), Methylocystis sp. (3/20), Methylomicrobiom sp. (1/20), each representative of Methylosarcina sp. (1), and a distant relative of Methyloglobus sp. (1). One of the sequences (pmoA 7) was unidentified. 


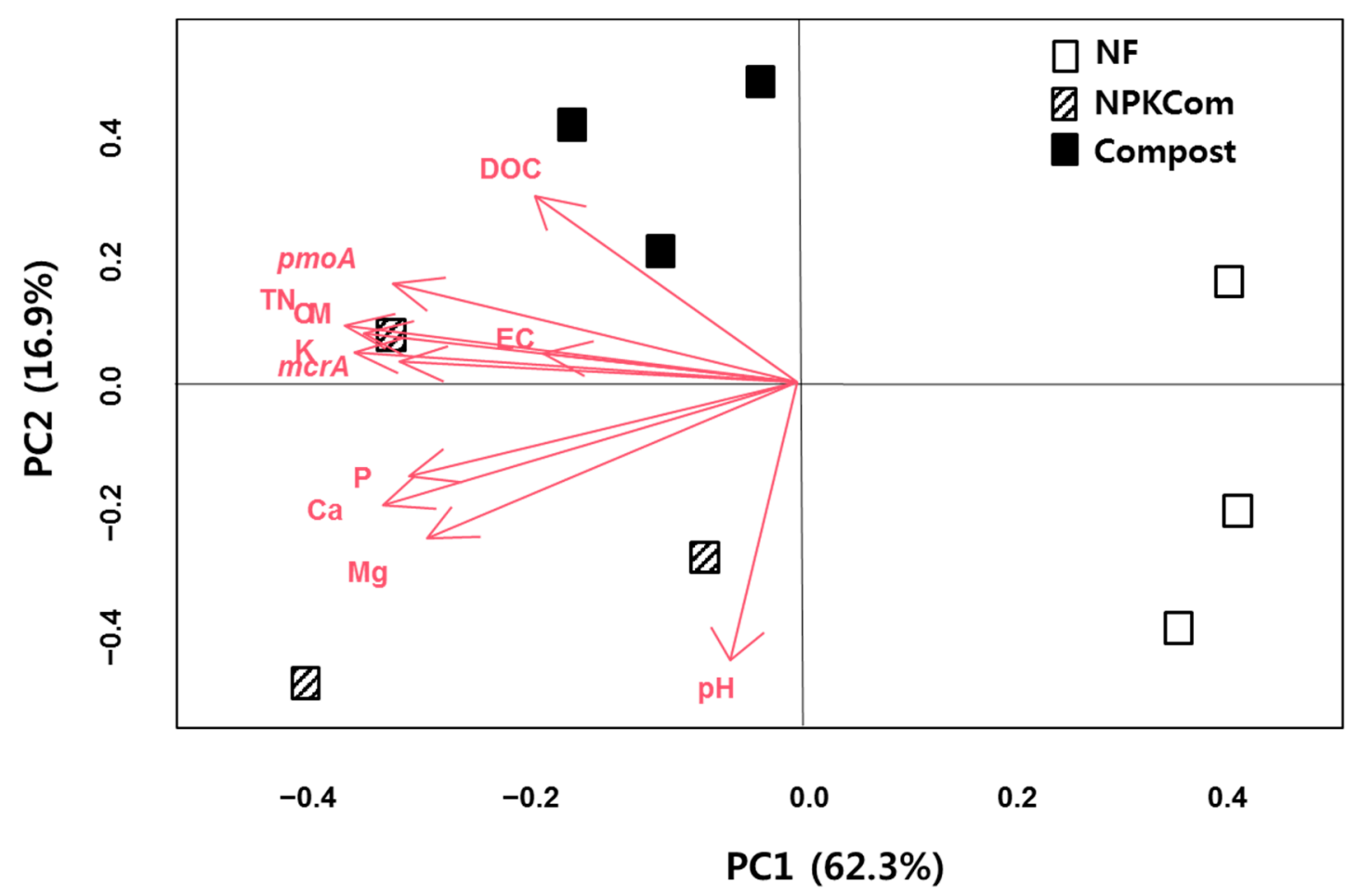

Figure 1. Principal component analysis (PCA) score plot of paddy fields under long-term compost fertilization based on the soil chemical properties and the abundance of methanogenesis and methane oxidation functional genes. NF-unfertilized control; NPKCom-chemical fertilizer (NPK)+compost; Com-compost.

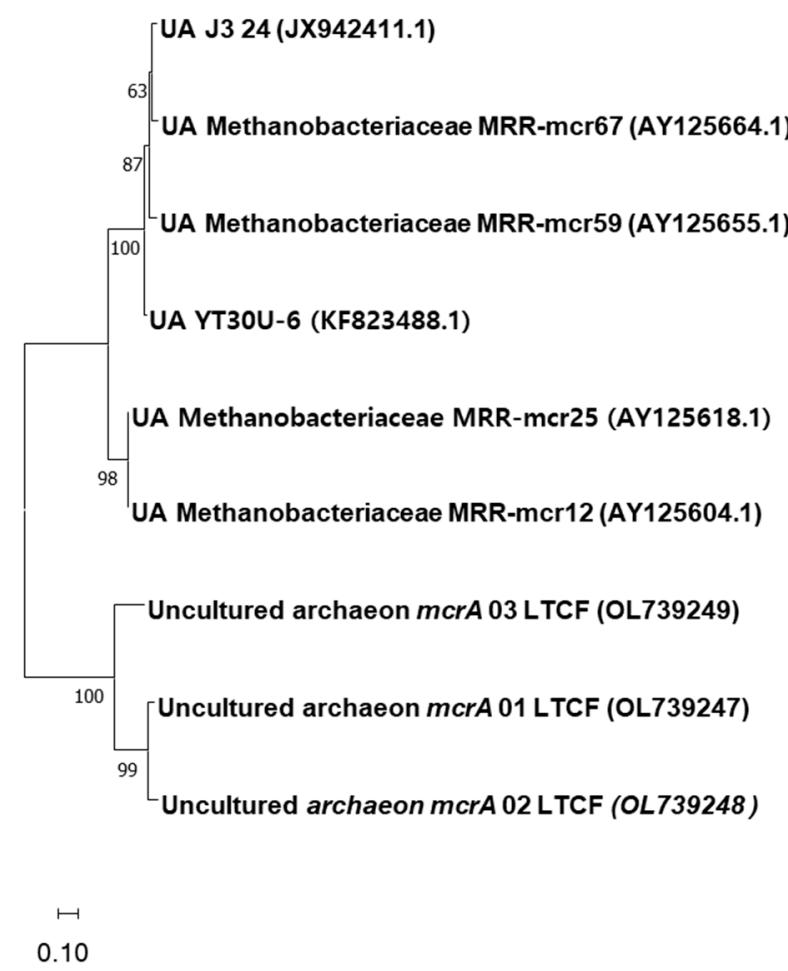

Figure 2. Phylogenetic tree showing the relationship between the partial mcrA DNA sequences of methanogens determined in this study with their closest identified sequences retrieved from GenBank. Bootstrap values are shown at the branch points. The tree is drawn to scale, with the branch lengths in the same unit as those of the evolutionary distances used to infer the phylogenetic tree. 


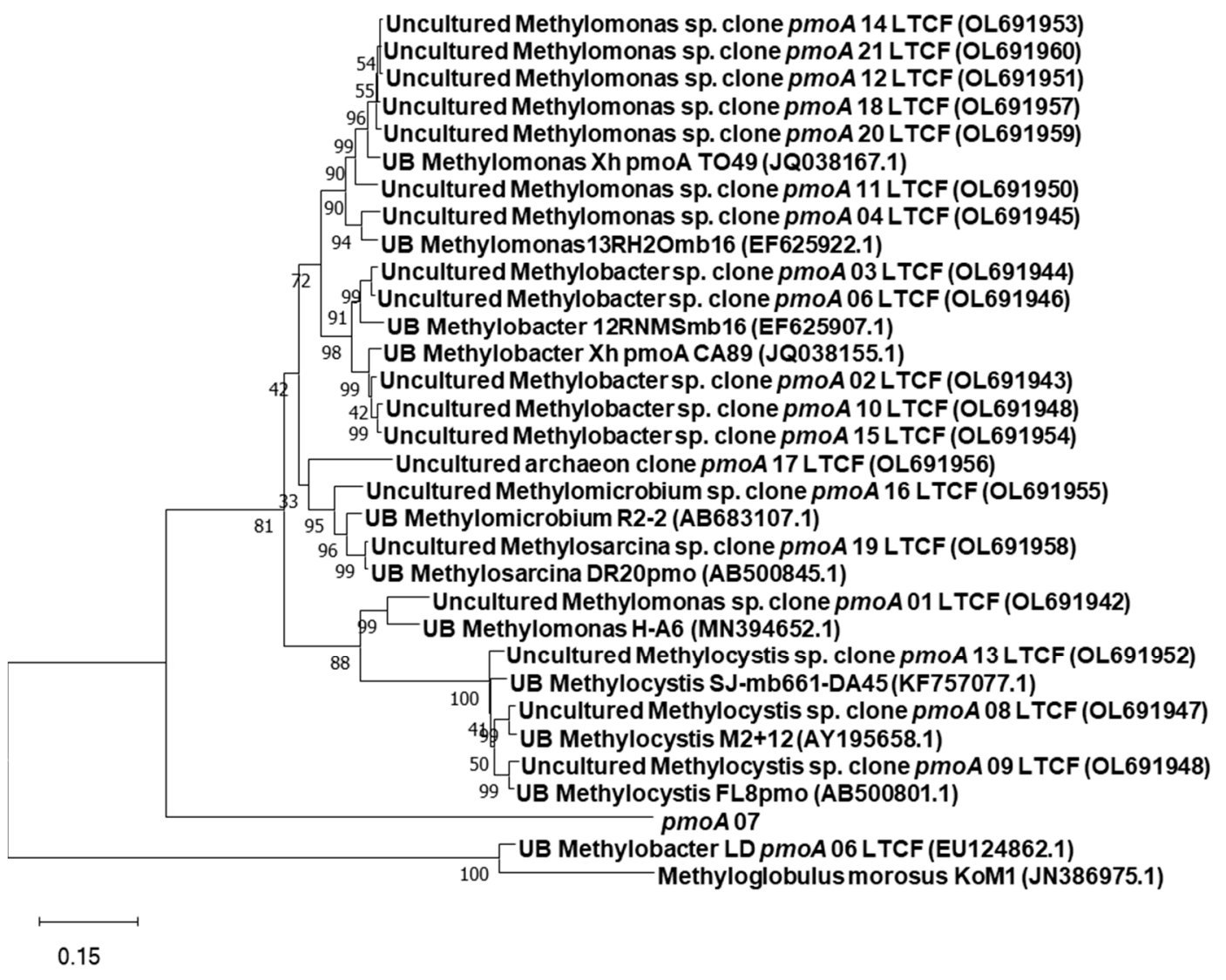

Figure 3. Phylogenetic tree showing the relationship between the partial $p m o A$ DNA sequences of methane oxidizing bacteria determined in this study with their closest identified sequences retrieved from GenBank. Bootstrap values are shown at the branch points. The tree is drawn to scale, with the branch lengths in the same unit as those of the evolutionary distances used to infer the phylogenetic tree.

\section{Discussion}

The long-term fertilization with compost and NPK+Compost containing rice straw and cattle manure altered the soil chemical properties of the paddy fields. These significant changes, particularly soil OM and nutrient contents under long-term fertilization, have also been observed in previous studies [11,35-39]. The increase in OM was mainly attributed to the significant increase in carbon input [40]. In the first year of organic treatment in the study by Pandey et al. [41] OM and $\mathrm{N}$ were seen to increase by $0.67 \%$ and $0.64 \%$, respectively. However, under long-term simulation, there is a net accumulation of OM and residual $\mathrm{N}$ concentrations, generally increasing the overall $\mathrm{OM}$ and $\mathrm{N}$ contents in paddy fields even after the end of the growing season. Labile and dissolved organic carbon pools also increased in the current study. This is in agreement with other studies, where amending paddy fields with organic fertilizers provided a potent source of labile $\mathrm{C}$ content rich in nutrients; thereby building higher labile organic $C[12,42,43]$, including organic acids [10,12]. For instance, a continuous manure application increased OM, DOC and various nutrient contents by 1.4-3.9 times higher than the unfertilized field [11].

The results of the current study showed that $m c r A$ and $p m o A$ gene abundance significantly increased in both Com and NPKCom treatments relative to the unfertilized paddy fields. In most cases, methane emission is positively correlated to the abundance of methanogens or the $m c r A$ gene $[11,15,44,45]$. At the tillering stage, where methane emission was previously observed to be high in the study of Zhang et al., [11], $m c r A$ gene abundances were all significantly higher in paddy fields with continuous manure application by 17-55 times than the unfertilized field and resulted in higher methane pro- 
duction potential. In addition, the abundance of methanotrophs and methane oxidation related genes have been observed to correlate with methane emission or an abundance of methanogenesis-related genes [10,45-47]. The significant increase in both $m c r A$ and $p m o A$ gene abundance in compost-fertilized fallow paddy fields in the current study indicated their potential for enhanced methanogenesis and methane oxidation. Multiple factors affect methanogenesis, the abundance of the $m c r A$ gene and methane oxidation, or the abundance of the $p m o A$ gene $[4,8]$. In the current study, the significant differences in soil chemical properties between the unfertilized and compost-fertilized paddy fields and the stronger PCA main loading factors attributed to TN, K, OM, Ca, pH and DOC implied that these variables cumulatively affected the abundance of the $m c r A$ and $p m o A$ genes. Under long-term fertilization, these variables were the most important factors affecting methanogenic, methanotrophic and microbial communities [10,11,38,44], and methane emission [48].

The increase in the nutrient content of paddy soils could relieve the nutrient limitation leading to an overall increase in microbial population; or the increased OM and labile DOC drives the enhanced activity of methanogenic archaeal communities, consequently increasing the $m c r A$ gene abundance. These situations were similarly observed in other studies, where the increase in $\mathrm{OM}, \mathrm{TN}$, labile $\mathrm{C}$ pools, and other soil nutrients led to increased microbial diversity and abundance $[38,40,49]$. These scenarios could also be true for methane-oxidizing bacterial communities. In addition to nutrient limitations, the activity of methane-oxidizing bacteria is mainly regulated by the availability of oxygen and methane and the presence of mineral nitrogen, where there is a strong positive correlation between the application of nitrogen fertilizer and methane oxidation [50,51]. Cai et al., [51] also observed that methanotrophic populations and methane oxidation rates were significantly stimulated by urea as a result of the relief of nitrogen constraint.

PCA plot and k-means clustering performed in this study supported a grouping according to compost fertilization treatments. There were distinct and separate clusters of the different treatments under long-term compost fertilization, when soil chemical properties and gene abundance were used to assess variabilities. The PCA analysis showed distinct clustering mainly by the effects of PC1, PC2 and PC3, explaining up to $88.57 \%$ cumulative loading. The implications of these mean that all three treatments showed variabilities in soil chemical properties and the abundance of $m c r A$ and $p m o A$ genes. Similar changes in the paddy fields occur across studies where different types of fertilizers change multiple aspects of the soil in terms of the physical, chemical, or biological components [12,38]. These changes occur over short-term fertilizer perturbations $[10,11,44]$ or long-term fertilization $[12,15,36,40]$ and resulted in different paddy fields with particular soil chemical characteristics $[38,48]$. The unfertilized paddy field in the current study was characterized by low nutrient soils with low abundances of mcrA and pmoA genes. The NPKCom and the Com treatments were generally characterized by soils with high nutrient contents and higher abundances of $m c r A$ and $p m o A$ genes with differences in $\mathrm{pH}$ and DOC content. Our results were consistent with previous studies where long-term compost fertilization resulted in paddy fields with high nutrient content with more diverse and abundant microbial communities $[12,38]$, which ultimately drive different soil biochemical processes, including methanogenesis and methane oxidation $[8,10,41,44]$.

To give an overview of microbial communities attributed to the $m c r A$ and $p m o A$ genes, clones of the genes were sequenced and reference sequences were obtained. Previous studies have observed that Methanobacteriaceae in anoxic rice paddies are associated with the rice roots and rhizosphere or on the bulk soil [52-54]. The results of the current study on the detection of Methanobacteriaceae could be attributed to straw amendments [55] and manure [56], whereby their input increased the diversity of methanogens in rice paddies with a predominance of the Methanobacteriaceae. Type I and type II methylotrophs occur in paddy fields with unsaturated water content and oxidize methane when conditions were suitable [57]. The predominance of type I MOB in the current study was consistent with other studies showing that long-term organic fertilization increased the abundance of 
type I MOB [36], while the abundance of type II decreased in manure and NPK+manure treatments [44]. Consequently, type I was found in paddy fields supplemented with fertilizers, while type II methanotrophs are generally found in native soils with low or no fertilization $[58,59]$, which is in line with the results of the current study, where more sequences of type I MOB were detected. The $m c r A$ and $p m o A$ gene sequences observed in the current study were mainly attributed to reference sequences known to respond well with compost or NPK+Compost application.

\section{Practical Implications of the Study}

Characteristic paddy soils with high nutrient content and high abundance for methanerelated functional genes attributed to methanogens and methane oxidizing bacteria that respond well to compost fertilization were established, even during the rice non-growing period due to long-term compost fertilization. This indicated the potential for methanogenesis and methane oxidation occurring in these paddy fields during the fallow period, especially when they are left in submerged conditions [13]. In addition, the results indicated that these characteristic paddy fields are 'primed'. They have a history of repeated fertilization, contain high abundance of methane-related functional genes, and potentially contain more responsive microbial communities. History [14,15], the abundance of $m c r A$ and $p m o A$ genes $[10-12,44,48,50]$, and the specific type of microorganisms $[16,50,56]$ are all critical factors regarding the subsequent methanogenesis and methane oxidation responses of these paddy fields to repeated fertilization with compost and NPK+Compost. The necessity to monitor how long-term compost fertilization affects soil chemical properties and functional gene abundance provides insights in paddy field ecosystems during the fallow period that could greatly influence methane transformations and subsequent responses of paddy fields to continued compost fertilization. Continuous monitoring helps create encompassing models and mitigation schemes that help extenuate anthropogenic methane emissions, while maximizing yield and maintaining soil fertility and productivity $[1,60]$.

\section{Conclusions}

This study showed that long-term compost fertilization containing cattle manure and rice straw or a combination of NPK and compost fertilization increased the OM, TN, $\mathrm{P}_{2} \mathrm{O}_{5}$ and $\mathrm{K}$ content in the paddy fields. Compost fertilization provided a more readily available DOC, while the addition of inorganic chemical fertilizer, NPK, in combination with compost resulted in paddy soils with higher $\mathrm{Ca}, \mathrm{Mg}$ and $\mathrm{pH}$. The changes in soil chemical properties of compost-fertilized paddy fields concurrently resulted in the increased abundance of methanogenesis and methane-oxidation-related genes as well as the overall soil variabilities among unfertilized, compost, and NPK+Compost-fertilized fields. Paddy fields under longterm compost fertilization are characterized by soils with increased nutrient content and an increased abundance of methanogenesis and methane-oxidation-related genes. These soil conditions are present even during the fallow period, indicating their potential impact on methane emission and methane oxidation during the fallow season or when rice paddies are recurrently amended with compost and NPK+Compost. The study clearly indicates that the soil and biological conditions in long-term compost-fertilized paddy fields are distinctly different from those of unfertilized paddy fields and these are the conditions that initially or continuously respond to different treatments and agricultural management practices in relation to methane emission and methane oxidation.

Supplementary Materials: The following are available online at https:/ / www.mdpi.com/article/ 10.3390/app12052652/s1, Table S1: characteristics of qPCR primer pair and programs [59,61-63]; Figure S1: k-means clustering and heatmap of the different treatments based on the soil chemical properties under long-term compost fertilization. EC-electrical conductivity; OM-organic matter; TN-total nitrogen; DOC-dissolved organic carbon. Table S2: Pearson correlation coefficient between the abundance of methanogenesis $(m c r A)$ and methane oxidation ( $p m o A)$ functional genes and soil chemical properties of paddy fields under long-term compost fertilization. 


\begin{abstract}
Author Contributions: Conceptualization, T.S. and A.R.C.; methodology, T.S. and S.L.; software, C.K. and A.R.C.; validation, T.-Y.H. and T.S.; formal analysis, D.I.W., C.K. and T.-Y.H.; investigation, D.I.W., C.K., S.L., H.C. and K.P.; resources, T.S., C.K. and S.L.; data curation, D.I.W., C.K., S.L., H.C. and K.P.; writing—original draft preparation, D.I.W. and C.K.; writing—review and editing, D.I.W., A.R.C., C.K. and T.S.; visualization, C.K.; supervision, T.S., Y.L. and S.L.; project administration, T.S., Y.L. and S.L. All authors have read and agreed to the published version of the manuscript.
\end{abstract}

Funding: This study was carried out with the support of PJ015584042021, Rural Development Administration, Republic of Korea.

\title{
Institutional Review Board Statement: Not applicable.
}

Informed Consent Statement: Not applicable.

Data Availability Statement: The sequences of the clones were submitted in the BankIt portal in NCBI and the accession numbers were mentioned in the Methods section.

Acknowledgments: We would like to acknowledge the technical advice of Hiie Nolvak and Jaak Truu on the conduct and analysis of qPCR.

Conflicts of Interest: The authors declare no conflict of interest.

\section{References}

1. Paustian, K.; Lehmann, J.; Ogle, S.; Reay, D.; Robertson, G.P.; Smith, P. Climate-smart soils. Nature 2016, 532, 49-57. [CrossRef] [PubMed]

2. $\quad$ Burns, R.G.; Nannipieri, P.; Benedetti, A.; Hopkins, D.W. Defining soil quality. In Microbiological Methods for Assessing Soil Quality; Bloem, J., Hopkins, D.W., Benedetti, A., Eds.; CABI Publishing: Cambridge, UK, 2006; pp. 15-22.

3. Schloter, M.; Nannipieri, P.; Sørensen, S.J.; van Elsas, J.D. Microbial indicators for soil quality. Biol. Fertil. Soils. 2018, 54, 1-10. [CrossRef]

4. Le Mer, J.; Roger, P. Production, oxidation, emission and consumption of methane by soils: A review. Eur. J. Soil Biol. 2001, 37, 25-50. [CrossRef]

5. Jackson, R.B.; Abernethy, S.; Canadell, J.G.; Cargnello, M.; Davis, S.J.; Féron, S.; Fuss, S.; Heyer, A.J.; Hong, C.; Jones, C.D.; et al. Atmospheric methane removal: A research agenda. Philos. Trans. R. Soc. A 2021, 379, 20200454. [CrossRef] [PubMed]

6. Linquist, B.A.; Adviento-Borbe, M.A.; Pittelkow, C.M.; van Kessel, C.; van Groenigen, K.J. Fertilizer management practices and greenhouse gas emissions from rice systems: A quantitative review and analysis. Field Crops Res. 2012, 135, 10-21. [CrossRef]

7. Carlson, K.M.; Gerber, J.S.; Mueller, N.D.; Herrero, M.; MacDonald, G.K.; Brauman, K.A.; West, P.C. Greenhouse gas emissions intensity of global croplands. Nat. Clim. Chang. 2017, 7, 63-68. [CrossRef]

8. Conrad, R. Microbial ecology of methanogens and methanotrophs. Adv. Agron. 2007, 96, 1-63.

9. Diacono, M.; Montemurro, F. Long-term effects of organic amendments on soil fertility. In Sustainable Agriculture; Lichtfouse, E., Hamelin, M., Navarette, M., Debaeke, P., Eds.; Springer: Berlin/Heidelberg, Germany, 2011; Volume 2, pp. $761-786$.

10. Yuan, J.; Yuan, Y.; Zhu, Y.; Cao, L. Effects of different fertilizers on methane emissions and methanogenic community structures in paddy rhizosphere soil. Sci. Total Environ. 2018, 627, 770-781. [CrossRef]

11. Zhang, W.; Sheng, R.; Zhang, M.; Xiong, G.; Hou, H.; Li, S.; Wei, W. Effects of continuous manure application on methanogenic and methanotrophic communities and methane production potentials in rice paddy soil. Agric. Ecosyst. Environ. 2018, 258, 121-128. [CrossRef]

12. Bhattacharyya, P.; Nayak, A.K.; Mohanty, S.; Tripathi, R.; Shahid, M.; Kumar, A.; Rao, K.S. Greenhouse gas emission in relation to labile soil C, N pools and functional microbial diversity as influenced by 39 years long-term fertilizer management in tropical rice. Soil Tillage Res. 2013, 129, 93-105. [CrossRef]

13. Cai, Z.C.; Tsuruta, H.; Minami, K. Methane emission from rice fields in China: Measurements and influencing factors. J. Geophys. Res. Atmos. 2000, 105, 17231-17242. [CrossRef]

14. Bodelier, P.L. Interactions between nitrogenous fertilizers and methane cycling in wetland and upland soils. Curr. Opin. Environ. Sustain. 2011, 3, 379-388. [CrossRef]

15. Jiang, Y.; Qian, H.; Huang, S.; Zhang, X.; Wang, L.; Zhang, L.; Shen, M.; Xiao, X.; Chen, F.; Zhang, H.; et al. Acclimation of methane emissions from rice paddy fields to straw addition. Sci. Adv. 2019, 5, eaau9038. [CrossRef] [PubMed]

16. Conrad, R.; Klose, M.; Noll, M.; Kemnitz, D.; Bodelier, P.L. Soil type links microbial colonization of rice roots to methane emission. Glob. Chang. Biol. 2008, 14, 657-669. [CrossRef]

17. Lyu, Z.; Shao, N.; Akinyemi, T.; Whitman, W.B. Methanogenesis. Curr. Biol. 2018, 28, R727-R732. [CrossRef]

18. Hakobyan, A.; Liesack, W. Unexpected metabolic versatility among type II methanotrophs in the Alphaproteobacteria. Biol. Chem. 2020, 401, 1469-1477. [CrossRef]

19. Daquiado, A.R.; Kuppusamy, S.; Kim, S.Y.; Kim, J.H.; Yoon, Y.E.; Kim, P.J.; Lee, Y.B. Pyrosequencing analysis of bacterial community diversity in long-term fertilized paddy field soil. Appl. Soil Ecol. 2016, 108, 84-91. [CrossRef] 
20. Heczko, J.; Gselman, A.; Turinek, M.; Bavec, M.; Kristl, J. Organic carbon content in soils of long-term field trial: Comparison of analytical methods. Agricultura 2011, 8, 17-22.

21. Bremner, J.M. Determination of nitrogen in soil by the Kjeldahl method. J. Agric. Sci. 1960, 55, 11-33. [CrossRef]

22. Samaddar, S.; Truu, J.; Chatterjee, P.; Truu, M.; Kim, K.; Kim, S.; Sa, T. Long-term silicate fertilization increases the abundance of Actinobacterial population in paddy soils. Biol. Fertil. Soils 2019, 55, 109-120. [CrossRef]

23. Jones, D.L.; Willett, V.B. Experimental evaluation of methods to quantify dissolved organic nitrogen (DON) and dissolved organic carbon (DOC) in soil. Soil Biol. Biochem. 2006, 38, 991-999. [CrossRef]

24. Basic Local Alignment Search Tool. Available online: https://blast.ncbi.nlm.nih.gov/ (accessed on 10 September 2021).

25. Tamura, K.; Stecher, G.; Peterson, D.; Filipski, A.; Kumar, S. MEGA6: Molecular evolutionary genetics analysis version 6.0. Mol. Biol. Evol. 2013, 30, 2725-2729. [CrossRef] [PubMed]

26. Thompson, J.D.; Higgins, D.G.; Gibson, T.J. CLUSTAL W: Improving the sensitivity of progressive multiple sequence alignment through sequence weighting, position-specific gap penalties and weight matrix choice. Nucleic Acids Res. 1994, 22, 4673-4680. [CrossRef] [PubMed]

27. Jukes, T.H.; Cantor, C.R. Evolution of protein molecules. In Mammalian Protein Metabolism; Academic Press: Cambridge, MA, USA, 1969; Volume 3, pp. 21-132.

28. Saitou, N.; Nei, M. The neighbor-joining method: A new method for reconstructing phylogenetic trees. Mol. Biol. Evol. 1987, $4,406-425$.

29. Felsenstein, J. Confidence limits on phylogenies: An approach using the bootstrap. Evolution 1985, 39, 783-791. [CrossRef] [PubMed]

30. SAS Institute Inc. Base Sas 9.4 Procedures Guide: Statistical Procedures, 2nd ed.; SAS Institute: Cary, NC, USA, 2013.

31. Metsalu, T.; Vilo, J. ClustVis: A web tool for visualizing clustering of multivariate data using Principal Component Analysis and heatmap. Nucleic Acids Res. 2015, 43, W566-W570. [CrossRef]

32. Tang, Y.; Horikoshi, M.; Li, W. Ggfortify: Unified interface to visualize statistical results of popular R packages. R J. 2016, 8, 474 . [CrossRef]

33. Rohart, F.; Gautier, B.; Singh, A.; Lê Cao, K.A. mixOmics: An R package for 'omics feature selection and multiple data integration. PLoS Comput. Biol. 2017, 13, e1005752. [CrossRef]

34. Weiner, J.; Weiner, M.J. Package 'pca3d'. 2020. Available online: http://www2.uaem.mx/r-mirror/web/packages/pca3d/pca3d. pdf (accessed on 25 September 2021).

35. Zheng, J.; Zhang, X.; Li, L.; Zhang, P.; Pan, G. Effect of long-term fertilization on C mineralization and production of CH4 and $\mathrm{CO}_{2}$ under anaerobic incubation from bulk samples and particle size fractions of a typical paddy soil. Agric. Ecosyst. Environ. 2007, 120, 129-138. [CrossRef]

36. Zheng, Y.; Zhang, L.M.; Zheng, Y.M.; Di, H.; He, J.Z. Abundance and community composition of methanotrophs in a Chinese paddy soil under long-term fertilization practices. J. Soils Sediments 2008, 8, 406-414. [CrossRef]

37. Tang, H.M.; Xiao, X.P.; Wang, K.; Li, W.Y.; Liu, J.; Sun, J.M. Methane and nitrous oxide emissions as affected by long-term fertilizer management from double-cropping paddy fields in Southern China. J. Agric. Sci. 2016, 154, 1378-1391. [CrossRef]

38. Guo, Z.; Han, J.; Li, J.; Xu, Y.; Wang, X. Effects of long-term fertilization on soil organic carbon mineralization and microbial community structure. PLOS ONE 2019, 14, e0211163.

39. Kang, H.; Yu, W.; Dutta, S.; Gao, H. Soil microbial community composition and function are closely associated with soil organic matter chemistry along a latitudinal gradient. Geoderma 2021, 383, 114744. [CrossRef]

40. Ma, L.; Lin-Zhang, Y.; Li-Zhong, X.; Ming-Xing, S.; Shi-Xue, Y.; Yun-Dong, L. Long-term effects of inorganic and organic amendments on organic carbon in a paddy soil of the Taihu Lake Region, China. Pedosphere 2011, 21, 186-196. [CrossRef]

41. Pandey, A.; Dou, F.; Morgan, C.L.; Guo, J.; Deng, J.; Schwab, P. Modeling organically fertilized flooded rice systems and its long-term effects on grain yield and methane emissions. Sci. Total Environ. 2021, 755, 142578. [CrossRef] [PubMed]

42. Zhang, H.M.; Wang, B.; Xu, M.; Fan, T. Crop yield and soil responses to long term fertilization on a red soil in southern China. Pedosphere 2009, 19, 199-207. [CrossRef]

43. Das, S.; Adhya, T.K. Effect of combine application of organic manure and inorganic fertilizer on methane and nitrous oxide emissions from a tropical flooded soil planted to rice. Geoderma 2014, 213, 185-192. [CrossRef]

44. Kong, D.; Li, S.; Jin, Y.; Wu, S.; Chen, J.; Hu, T.; Wang, H.; Liu, S.; Zou, J. Linking methane emissions to methanogenic and methanotrophic communities under different fertilization strategies in rice paddies. Geoderma 2019, 347, 233-243. [CrossRef]

45. Lee, H.J.; Kim, S.Y.; Kim, P.J.; Madsen, E.L.; Jeon, C.O. Methane emission and dynamics of methanotrophic and methanogenic communities in a flooded rice field ecosystem. FEMS Microbiol. Ecol. 2014, 88, 195-212. [CrossRef]

46. Freitag, T.E.; Toet, S.; Ineson, P.; Prosser, J.I. Links between methane flux and transcriptional activities of methanogens and methane oxidizers in a blanket peat bog. FEMS Microbiol. Ecol. 2010, 73, 157-165. [CrossRef]

47. Fernández-Baca, C.P.; Truhlar, A.M.; Omar, A.E.H.; Rahm, B.G.; Walter, M.T.; Richardson, R.E. Methane and nitrous oxide cycling microbial communities in soils above septic leach fields: Abundances with depth and correlations with net surface emissions. Sci. Total Environ. 2018, 640, 429-441. [CrossRef] [PubMed]

48. Hou, P.; Yu, Y.; Xue, L.; Petropoulos, E.; He, S.; Zhang, Y.; Pandey, A.; Xue, L.; Yang, L.; Chen, D. Effect of long term fertilization management strategies on methane emissions and rice yield. Sci. Total Environ. 2020, 725, 138261. [CrossRef] [PubMed] 
49. Qin, Y.; Liu, S.; Guo, Y.; Liu, Q.; Zou, J. Methane and nitrous oxide emissions from organic and conventional rice cropping systems in Southeast China. Biol. Fertil. Soils 2010, 46, 825-834. [CrossRef]

50. Mohanty, S.R.; Bodelier, P.L.; Floris, V.; Conrad, R. Differential effects of nitrogenous fertilizers on methane-consuming microbes in rice field and forest soils. Appl. Environ. Microbiol. 2006, 72, 1346-1354. [CrossRef]

51. Cai, Y.; Zheng, Y.; Bodelier, P.L.; Conrad, R.; Jia, Z. Conventional methanotrophs are responsible for atmospheric methane oxidation in paddy soils. Nat. Commun. 2016, 7, 11728. [CrossRef]

52. Fey, A.; Conrad, R. Effect of temperature on carbon and electron flow and on the archaeal community in methanogenic rice field soil. Appl. Environ. Microbiol. 2000, 66, 4790-4797. [CrossRef]

53. Lueders, T.; Friedrich, M. Archaeal population dynamics during sequential reduction processes in rice field soil. Appl. Environ. Microbiol. 2000, 66, 2732-2742. [CrossRef]

54. Lueders, T.; Chin, K.J.; Conrad, R.; Friedrich, M. Molecular analyses of methyl-coenzyme M reductase $\alpha$-subunit (mcrA) genes in rice field soil and enrichment cultures reveal the methanogenic phenotype of a novel archaeal lineage. Environ. Microbiol. 2001, 3, 194-204. [CrossRef]

55. Bao, Q.; Huang, Y.; Wang, F.; Nie, S.; Nicol, G.W.; Yao, H.; Ding, L. Effect of nitrogen fertilizer and/or rice straw amendment on methanogenic archaeal communities and methane production from a rice paddy soil. Appl. Microbiol Biotechnol. 2016, 100, 5989-5998. [CrossRef]

56. Kim, S.Y.; Pramanik, P.; Bodelier, P.L.; Kim, P.J. Cattle manure enhances methanogens diversity and methane emissions compared to swine manure under rice paddy. PLoS ONE 2014, 9, e113593. [CrossRef]

57. Henckel, T.; Friedrich, M.; Conrad, R. Molecular analyses of the methane-oxidizing microbial community in rice field soil by targeting the genes of the $16 \mathrm{~S}$ rRNA, particulate methane monooxygenase, and methanol dehydrogenase. Appl. Environ. Microbiol. 1999, 65, 1980-1990. [CrossRef] [PubMed]

58. Bodelier, P.L.; Roslev, P.; Henckel, T.; Frenzel, P. Stimulation by ammonium-based fertilizers of methane oxidation in soil around rice roots. Nature 2000, 403, 421-424. [CrossRef] [PubMed]

59. Alam, M.S.; Jia, Z. Inhibition of methane oxidation by nitrogenous fertilizers in a paddy soil. Front. Microbiol. 2012, 3, 246. [CrossRef]

60. Kim, C.; Walitang, D.I.; Sa, T. Methanogenesis and methane oxidation in paddy fields under organic fertilization. Korean J. Environ. Agric. 2021, 40, 295-312. [CrossRef]

61. Steinberg, L.M.; Regan, J.M. Phylogenetic comparison of the methanogenic communities from an acidic, oligotrophic fen and an anaerobic digester treating municipal wastewater sludge. Appl. Environ. Microbiol. 2008, 74, 6663-6671. [CrossRef]

62. Poulsen, M.; Schwab, C.; Jensen, B.B.; Engberg, R.M.; Spang, A.; Canibe, N.; Urich, T. Methylotrophic methanogenic Thermoplasmata implicated in reduced methane emissions from bovine rumen. Nat. Commun. 2013, 4, 1428. [CrossRef]

63. Costello, A.M.; Lidstrom, M.E. Molecular characterization of functional and phylogenetic genes from natural populations of methanotrophs in lake sediments. Appl. Environ. Microbiol. 1999, 65, 5066-5074. [CrossRef] 